\title{
More than a century of bathymetric observations and present-day shallow sediment characterization in Belfast Bay, Maine, USA: implications for pockmark field longevity
}

\author{
Laura L. Brothers • Joseph T. Kelley • \\ Daniel F. Belknap • Walter A. Barnhardt • \\ Brian D. Andrews • Melissa Landon Maynard
}

Received: 25 August 2010 / Accepted: 20 January 2011

(C) Springer-Verlag (outside the USA) 2011

\begin{abstract}
Mechanisms and timescales responsible for pockmark formation and maintenance remain uncertain, especially in areas lacking extensive thermogenic fluid deposits (e.g., previously glaciated estuaries). This study characterizes seafloor activity in the Belfast Bay, Maine nearshore pockmark field using (1) three swath bathymetry datasets collected between 1999 and 2008, complemented by analyses of shallow box-core samples for radionuclide activity and undrained shear strength, and (2) historical bathymetric data (report and smooth sheets from 1872, 1947, 1948). In addition, because repeat swath bathymetry surveys are an emerging data source, we present a selected literature review of recent studies using such datasets for seafloor change analysis. This study is the first to apply the method to a pockmark field, and characterizes macro-scale $(>5 \mathrm{~m})$ evolution of tens of square kilometers of highly irregular seafloor. Presence/absence analysis yielded no change in pockmark frequency or distribution over a 9-year period (1999-2008). In that time pockmarks did not detectably enlarge, truncate, elongate, or combine. Histor-
\end{abstract}

L. L. Brothers $(\bowtie) \cdot$ W. A. Barnhardt $\cdot$ B. D. Andrews

Woods Hole Coastal \& Marine Science Center,

U.S. Geological Survey,

384 Woods Hole Rd.,

Woods Hole, MA 02543-1598, USA

e-mail: lbrothers@usgs.gov

J. T. Kelley • D. F. Belknap

Department of Earth Sciences, Bryand Global Sciences Center, University of Maine,

Orono, ME 04469-5711, USA

M. L. Maynard

Department of Civil and Environmental Engineering,

Boardman Hall, University of Maine,

Orono, ME 04469-5711, USA ical data indicate that pockmark chains already existed in the 19th century. Despite the lack of macroscopic changes in the field, near-bed undrained shear-strength values of less than $7 \mathrm{kPa}$ and scattered downcore ${ }^{137} \mathrm{Cs}$ signatures indicate a highly disturbed setting. Integrating these findings with independent geophysical and geochemical observations made in the pockmark field, it can be concluded that (1) large-scale sediment resuspension and dispersion related to pockmark formation and failure do not occur frequently within this field, and (2) pockmarks can persevere in a dynamic estuarine setting that exhibits minimal modern fluid venting. Although pockmarks are conventionally thought to be long-lived features maintained by a combination of fluid venting and minimal sediment accumulation, this suggests that other mechanisms may be equally active in maintaining such irregular seafloor morphology. One such mechanism could be upwelling within pockmarks induced by near-bed currents.

\section{Introduction}

Since their scientific discovery by King and MacLean (1970), pockmarks remain one of the most widespread and enigmatic subaqueous landforms. Today, pockmark fields are known to occur in a variety of settings worldwide (e.g., Hovland and Judd 1988; Fleischer et al. 2001; Mazurenko and Soloviev 2003), including deltas (Nelson et al. 1979), fjords (e.g., Webb et al. 2009), rias (e.g., Iglesias and García-Gil 2007), and previously glaciated estuaries (e.g., Fader 1991), as well as in areas of petroleum production (e.g., Tjelta et al. 2007) and gas hydrate occurrence (e.g., Vaular et al. 2010). Fluid escape is commonly invoked for pockmark formation and maintenance (cf. Judd and Hovland 2007), and in some areas 
they actively vent freshwater and/or methane (e.g., Whiticar 2002; Hustoft et al. 2009). However, the initiation of a large pockmark has never been observed directly, and in addition to fluid venting, other mechanisms could play a role in their origin (sensu Paull et al. 2002), alteration (e.g., Bøe et al. 1998) and preservation (e.g., Josenhans et al. 1978).

In assessments of pockmark field longevity, it is important to constrain the frequency of pockmark formation, and if applicable, pockmark demise. Contrasting with the current wealth of information on global pockmark occurrence, much less is known about their longer-term activity and persistence. This is particularly relevant in nearshore settings where fluid venting appears to be minimal (e.g., Ussler et al. 2003), and mechanisms for pockmark formation are less apparent. Indeed, the need for extended monitoring has increasingly been emphasized since the turn of the century (e.g., Judd and Hovland 2007; Hammer et al. 2009; Hovland et al. 2010).

Within this context, bathymetric data spanning more than a century were evaluated for a well-studied pockmark field located in Belfast Bay, Maine (Fig. 1), including more recent repeat swath bathymetry surveys. Despite extensive research (cf. below), the field's activity pattern and mechanisms responsible for pockmark formation and maintenance remain unresolved. Moreover, this field may be representative of other pockmark fields found in previously glaciated estuaries, also lacking thermogenic fluids. Pockmark field longevity was assessed based on (1) co-located high-resolution swath bathymetry surveys collected over a 9-year period (1999-2008), coupled with radionuclide and shear-strength analyses of shallow core samples, and (2) historical datasets from 1872, 1947, and 1948.

\section{Physical setting}

Igneous and metamorphic rocks frame the coast of Maine, with no evidence of petroleum-bearing sedimentary rocks (Osberg et al. 1985). Differential erosion over millions of years has shaped the irregular coastal and inner shelf regions, and Holocene sea-level rise has formed numerous estuaries and bays (Kelley 1987; Belknap et al. 1987; Barnhardt et al. 1996).

Late Wisconsinan glaciers retreated from the Maine coast between 15 and $13 \mathrm{ka}$ (Dorion et al. 2001), leaving heterogeneous deposits of till, glacial outwash, and glacialmarine mud across the present seafloor (Belknap and Shipp 1991). Glacial-marine (GM) muddy sediments commonly cover rock and till seaward of the late Pleistocene marine limit (Thompson and Borns 1985). Stratified GM sediment is the most common deposit along the inner shelf of northern New England and the Canadian Maritimes, and completely fills some bedrock basins with more than $50 \mathrm{~m}$ of sediment (King and Fader 1986; Kelley and Belknap 1991; Barnhardt et al. 1997).
Fig. 1 Digital terrain model (hill-shaded bathymetry illuminated from $250^{\circ}$ ) and bathymetry of the Belfast Bay pockmark field from the 2006 USGS swath bathymetry survey (after Andrews et al. 2010). Box-core collection sites are indicated by crosses. Note that two box cores collected in the same pockmark are represented by only one cross

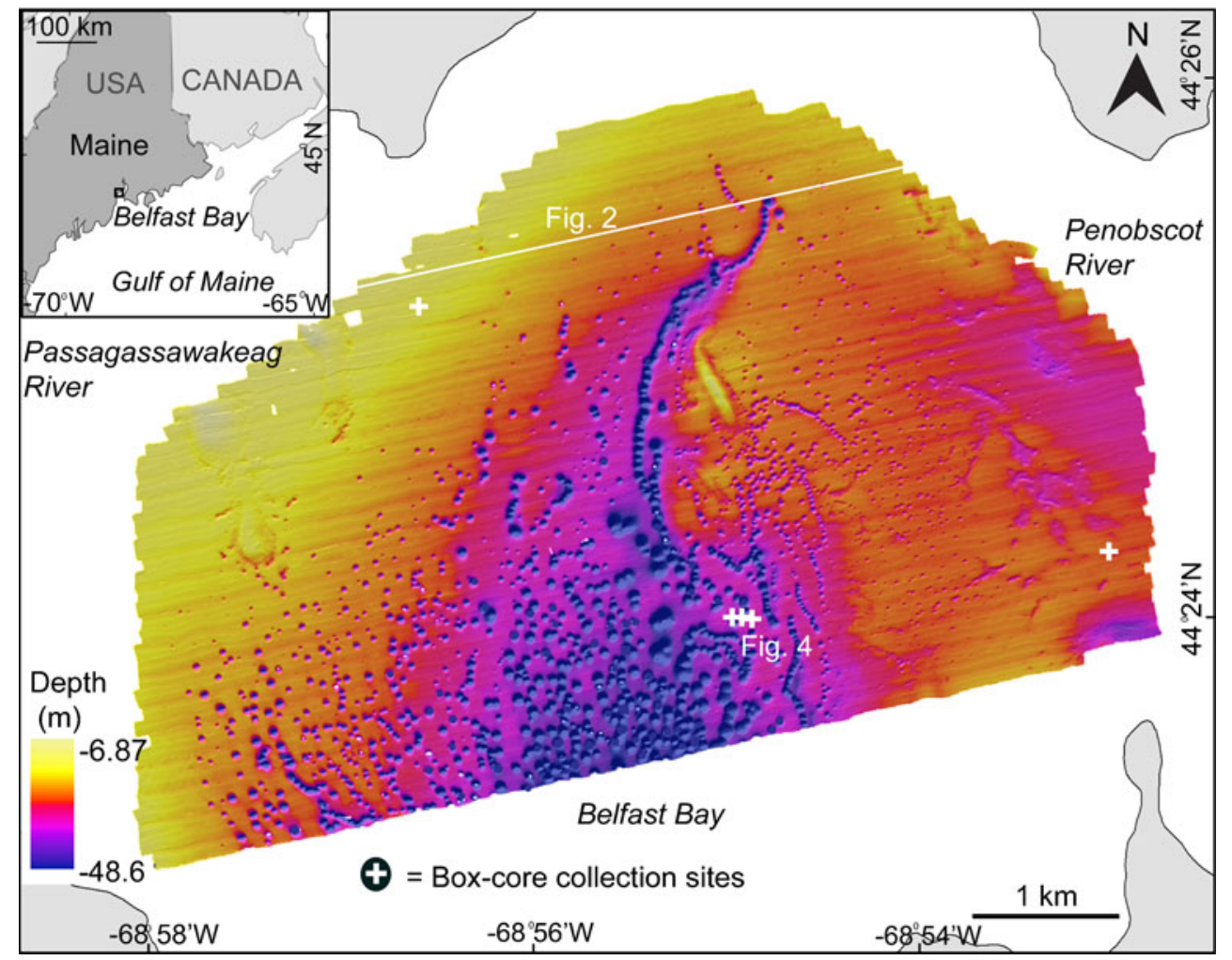


Isostatic effects of glaciation strongly influenced local sea level during the late Quaternary (Barnhardt et al. 1995). Marine incursion accompanied deglaciation, with maximum sea level occurring approx. 60-70 m higher than along today's coast. Within 2,000 years, further ice retreat and associated isostatic uplift caused sea level to fall to approx. $60 \mathrm{~m}$ below the present-day level (12.5 cal. ka), at which point most of Belfast Bay would have been dry land. Since then, sea level has risen at varying rates (Kelley et al. 2010). At many locations, a transgressive surface of erosion is observed, with Holocene mud or sand overlying glacial sediment (Belknap et al. 1994; Barnhardt et al. 1997). This erosive surface post-dates the lowstand, and thus any sediment overlying it was deposited during the last 12.5 cal. ka.

Belfast Bay is a protected, shallow $(<70 \mathrm{~m})$, muddy estuary located at the head of Penobscot Bay. The embayment has a mean tidal range of $3.1 \mathrm{~m}$. It is fed by a small river, the Passagassawakeag, and is within $20 \mathrm{~km}$ of the Penobscot River $\left(346 \mathrm{~m}^{3} \mathrm{~s}^{-1}\right.$ mean discharge; PEARL 2011). Although bedrock-channeled rivers transport sediment during periods of high discharge in the region (Fenster et al. 2001; Brothers et al. 2008), sediment introduction in Belfast Bay is much less than the available accommodation space. Pockmarks typify the embayment's bathymetry and occupy $5.8 \mathrm{~km}^{2}$, or $24 \%$ of the mapped seafloor (Andrews et al. 2010). Three-dimensional models of Penobscot Bay's circulation suggest that near-bottom currents in Belfast Bay are minimal, and generally do not exceed $0.2 \mathrm{~ms}^{-1}$ in any direction (Xue et al. 2000).

Belfast Bay pockmark field: active venting?

Geophysical surveys have revealed pockmarks and shallow natural gas, though not always coincident, within most muddy estuaries along Maine's coast. Moreover, geochemical analyses have confirmed the presence of microbially generated methane in seafloor sediments, in small amounts within $1 \mathrm{~m}$ of the seafloor and in ignitable quantities at depths exceeding $5 \mathrm{~m}$ (Barnhardt et al. 1997; Christian 2000; Ussler et al. 2003). Acoustic turbidity and enhanced reflectors occur in $24 \%$ of the field, but Belfast Bay does not contain distinct gas "chimneys" such as are found in other pockmark fields (Judd and Hovland 2007). Nor does the field exhibit paleo-pockmarks, or channels in CHIRP sonar data (Fig. 2). The pockmarks occur only within Holocene mud, and do not penetrate below the Holocene/ Pleistocene unconformity, thus confining pockmark formation to the Holocene (Rogers et al. 2006; Andrews et al. 2010).

Because of the ubiquity of shallow natural gas, methane escape has often been hypothesized as a key mechanism for pockmark formation in the area (e.g., Scanlon and Knebel 1989; Kelley et al. 1994). Rogers et al. (2006) proposed that lakes, marshes, and bogs that existed offshore when sea level was lower than at present provided the organic
Fig. 2 An interpreted CHIRP sonar profile in the northern sector of the study area with minimal pockmarks (after Andrews et al. 2010; see Fig. 1 for location). Depth conversions are based on sound velocity of $1,500 \mathrm{~ms}^{-1}$ in both water and sediment. $M$ Holocene estuarine/ bay mud, $E$ distinct reflector hypothesized to be the source bed for biogenically derived methane, $U$ Pleistocene/Holocene unconformity, $G M$ glacialmarine sediment, $N G$ natural gas, $a$ intrasedimentary doming (cf. Judd and Hovland 2007) potentially caused by a lag deposit or gas migration, $b$ potential bioherm

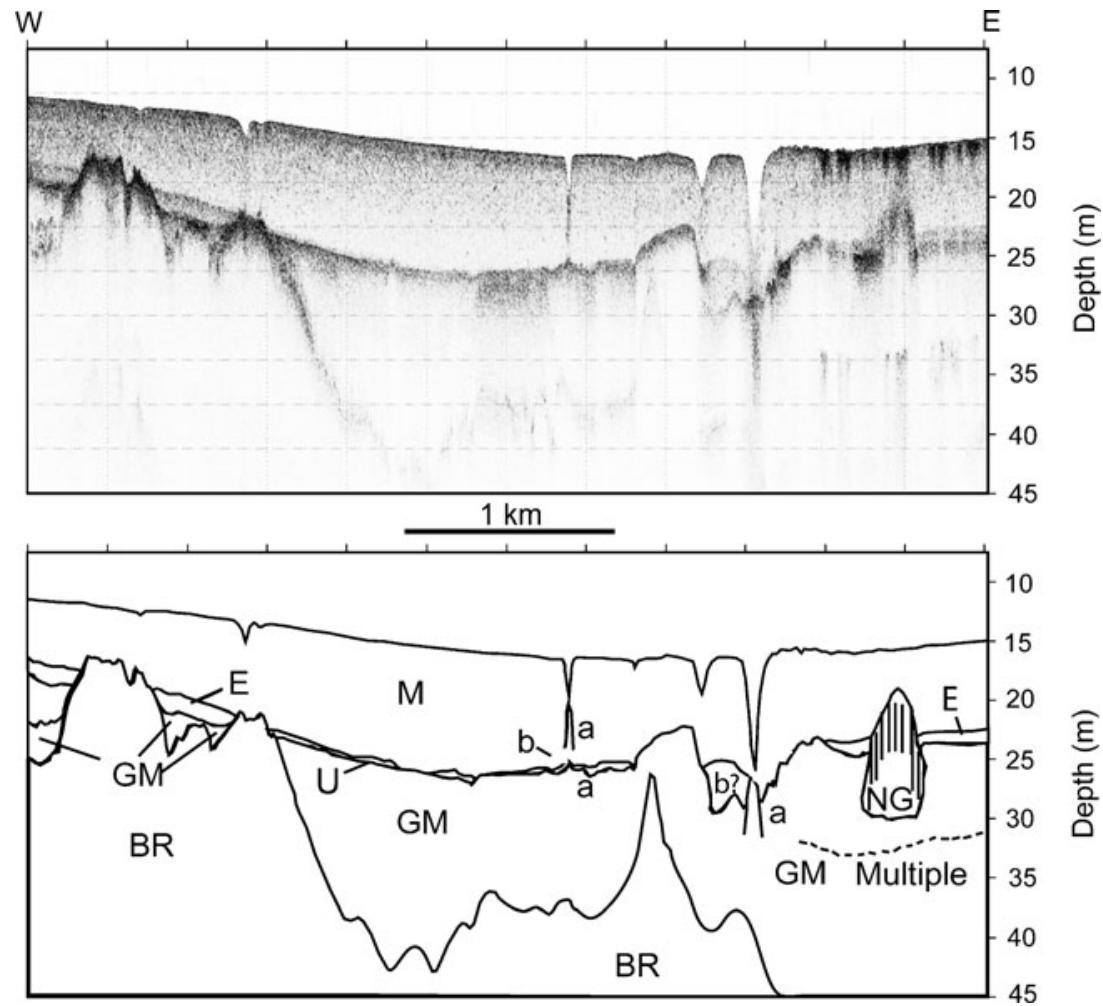


material that evolved into the methane in today's seafloor, and by inference, escaped to form Belfast Bay's pockmarks. Recently, Kelley et al. (2010) verified the presence of submerged organic deposits, with the discovery of drowned freshwater wetland and estuarine deposits nearby in the northwestern Gulf of Maine.

In a 1989 analog sidescan sonar survey of the bay, Kelley et al. (1994) captured an image of material apparently ejecting from a pockmark, and interpreted it as a fluid-escape event analogous to what may form the depressions. In addition, pockmarks identified in the concurrent bathymetric trace had slopes of $30^{\circ}$. Such steep slopes in a muddy estuarine seafloor would presumably slump without reinforcement by venting fluids, and Kelley et al. (1994) interpreted the morphology as an indication of relatively frequent venting activity. Indeed, Andrews et al. (2010) reported pockmark walls commonly exceeding even $40^{\circ}$ in the bay.

Further assessments of the field's activity came from Gontz' (2002) comparison of a 1989 and a 1999 sidescan sonar survey, revealing a $32 \%$ apparent change whereby many pockmarks disappeared or were initiated in the 10year time span. However, due to an unquantifiable error associated with different and older geopositioning systems (Loran C and DGPS), and without detailed information on sidescan sonar towfish layback, these results are now considered unreliable. Other evidence consistent with ongoing pockmark activity in the bay and along the Gulf of Maine coast includes remote-operated vehicle (ROV) records of turbidity (Belknap 1991; Arnold 2002), and local mariners' observations of turbid water, bubbles, and sediment plumes (cf. Kelley et al. 1994; Rogers et al. 2006).

Unlike other fields associated with methane venting (e.g., Hovland et al. 2005), methane-derived authigenic carbonate has never been found in the bay (Barnhardt et al. 1997; Ussler et al. 2003). Small holes within and around the pockmarks (Arnold 2002) may reflect venting, and could be considered unit pockmarks (Hovland et al. 1984). These are small depressions $(<5 \mathrm{~m}$ diameter $)$ that often surround larger pockmarks, and are considered artifacts of an expulsion event (Hovland and Judd 1988). In the present case, however, some of these holes undoubtedly relate to the abundance of burrowing fauna (e.g., the lobster Homarus americanus, and the wolf fish Anarhichas lupus; David Townsend, personal communication), and to anthropogenic impacts (e.g., fishing, dragging, mooring). Although fauna associated with methane have not been identified, pockmark-related fishing practices do exist in the region. In Belfast Bay, lobster fishermen preferentially set traps in the pockmarks when seafloor thermal conditions are favorable (Bill Sneed, personal communication). In other regional fields, fishermen intentionally avoid placing their gear within depressions they call "death holes"; ascribing poor fishing to alleged methane escape at these sites (Josh Conover, Scott Keenan, personal communication).

Ussler et al. (2003) conducted a detailed geochemical survey in Belfast Bay that included usage of a towed metaloxide methane sensor, and pore-fluid chromatographic and isotopic analyses on samples collected from gravity cores of $1.1 \mathrm{~m}$ average length and $1.9 \mathrm{~m}$ maximum length. Neither approach revealed significant amounts of methane or, in the cores, freshwater. Those authors also interpreted downcore modern carbon measurements as indications that the pockmarks were actively filling in, even though one third of their samples collected within pockmarks at the same depth intervals produced pre-Holocene dates. They overall concluded that "the combined data from our geochemical surveys provide no compelling evidence for especially active methane production in the shallow subseafloor of Belfast Bay ... thus these pockmarks may be inactive". Nevertheless, Rogers et al. (2006) argued that this could be explained by the shortness of the cores used in the earlier study, and the fact that their locations did not all coincide with sites where seismic-reflection records pinpointed natural gas. From the numerous observations described above, it is evident that Belfast Bay's current activity status remains controversial.

\section{Materials and methods}

\section{Bathymetry}

Three high-resolution swath bathymetry surveys were completed in Belfast Bay on 28 May 1999, 17 September 2006, and 24 September 2008. The US National Oceanic and Atmospheric Administration (NOAA) conducted the 1999 multibeam survey aboard the R/V Rude with a Reson SeaBat $9003(455 \mathrm{kHz})$ shallow-water sonar system, at $50 \%$ multibeam coverage over approx. $42.5 \mathrm{~km}^{2}$. There were 40 soundings per ping with an average swath width of $108^{\circ}$ after editing. Geopositioning was determined by a NAVSTAR global positioning system (GPS), augmented by the US Coast Guard differential GPS. Data were acquired using Triton-Elics' ISIS software version 4.28, and processed shipside using CARIS HIPS System version 4.2.7. Data were binned at $3 \times 3 \mathrm{~m}$ resolution, and NOAA produced a $20 \times 20 \mathrm{~m}$ grid of the field (NOAA 2000).

In cooperation with the University of Maine, the U.S. Geological Survey (USGS) conducted the two subsequent surveys with a bow-mounted Systems Engineering and Assessment (SEA Group, Somerset) SwathPlus Interferometric sonar $(234 \mathrm{kHz})$ onboard the R/V Rafael. Swath width ranged from 75 to $100 \mathrm{~m}$ and lines were spaced $100 \mathrm{~m}$ apart. A real-time kinematic GPS signal sent from a 
base station onshore in Belfast, Maine provided position coordinates. Sound velocity casts were collected every 2 $3 \mathrm{~h}$ to correct for changes in the speed of sound within the water column. Interferometric sonar data were acquired and initially processed with Swath Plus and SEA Swath Processor software. Raw data were binned at $0.1 \times 0.1 \mathrm{~m}$ resolution. A final manual line-by-line editing of the data was completed using CARIS HIPS 6.0. In 2006, CHIRP sonar data were concurrently collected with an EdgeTech FSSB 424 system operating at $4-24 \mathrm{kHz}$. Those initial results are presented in Andrews et al. (2010).

The US Coast Guard had conducted the two earliest surveys of the bay in 1872-H1106 and H1258 (US Coast Survey 1872a,b) - collecting depth soundings with leadlines and poles, and positioning by sextants and triangulation with topographic stations. No official Descriptive Reports exist for those surveys. In 1947 the US Coast and Geodetic Survey (USCGS) conducted survey H7198, to update for hazards and generally coinciding with survey H1106 (USCGS 1947). That survey has a Descriptive Report, and was conducted with a fathometer, graphic recorder, hand leadline and pole (USCGS 1948). Positioning was by the same methods as those of the earlier surveys, and soundings were projected on the basis of aerial photographs. Because the positioning, projection, instrumentation, and line spacing of these historical surveys differ markedly from those of the modern surveys, in the present study these data are compared only in terms of pockmark presence and general feature position.

\section{Difference analysis}

Selected data from the $2006\left(25 \mathrm{~km}^{2}\right)$ and $2008\left(12.7 \mathrm{~km}^{2}\right)$ surveys can confidently be compared with the 1999 dataset, because the surveys share the same trackline orientation, and the USGS collected $100 \%$ bathymetric coverage. All datasets were gridded at $5 \times 5 \mathrm{~m}$ resolution, and the 1999 dataset was further edited in CARIS HIPs. This resolution was chosen because (1) all datasets were compatible in this case; (2) it offers a computationally non-intensive baseline to assess $\mathrm{x}, \mathrm{y}$, or $\mathrm{z}$ directional offsets, the presence of which diminishes the usefulness of higher-resolution comparison; and (3) one can distinguish pockmarks from the background seafloor and potential survey artifacts with very high confidence. All gridded surfaces were imported into Fledermaus (IVS 3d, New Brunswick), whereby each grid was converted into a digital terrain model file, then exported into ArcGIS (ESRI, version 9.2.) to generate a 32-bit floating-point bathymetric grid. In ArcMap rasterized datasets were subtracted using the Math toolbox Minus tool. Pockmarks were extracted and counted by methods described in Andrews et al. (2010).
Preliminary evaluation found small $(1-5 \mathrm{~m})$, consistently oriented offsets between the datasets, attributed to differences in geopositioning and vessel configuration. Despite shifting and aligning based on seafloor features that were unlikely to have changed overtime (moraines), perfect three-dimensional registration was not achieved. In view of the steep pockmark slopes (approx. 20-40 cf. above), even a minimal lateral offset would result in substantial volumetric changes. For this reason, data evaluation was restricted to pockmark presence/absence and any changes in morphology indicated by offset symmetry.

\section{Cores}

Six shallow sediment cores $(21-52 \mathrm{~cm}$ length) were collected using a GOMEX box corer (Boland and Rowe 1991) from aboard the R/V Argo Maine in August 2008, four within, two at the outskirts of the pockmark field (Fig. 1; see below for more information on core location). In each case, the $20 \times 20 \times 50 \mathrm{~cm}$ box was subsampled onboard ship by manual insertion of a Lexan sleeve (inner diameter $9.2 \mathrm{~cm}$ ) into the center where the sediment was least disturbed. All subsampled cores were subsequently transported to University of Maine laboratories with care to minimize mechanical disturbance.

Two cores collected for radionuclide analysis were frozen and then sliced into 2-cm-thick, uniform "cookies". Analysis was conducted using the University of Maine Canberra germanium gamma ray detector and counter.

Four other cores were transported to the University of Massachusetts Amherst Geotechnical laboratory where the undrained shear strength, $\mathrm{s}_{\mathrm{u}}$, was measured over the upper $\sim 0.2 \mathrm{~m}$ using a miniature T-Bar penetrometer. The setup included a T-bar (4.1 mm diameter, $25.4 \mathrm{~mm}$ length) attached via a thin rod (3.6 mm diameter) to a $49 \mathrm{~N}$ load cell. The T-bar was inserted at a constant rate using a computer for a servo-controlled screw jack motor, with simultaneous acquisition of penetration resistance loading. Undrained shear strength was determined using the following relationship:

$\mathrm{s}_{\mathrm{u}}=\mathrm{q}_{\mathrm{t}-\mathrm{corr}} / \mathrm{N}$

where $\mathrm{q}_{\mathrm{t}-\mathrm{corr}}$ is the load corrected for measured T-bar shaft friction, and $\mathrm{N}$ a factor, typically 14 , which is correlated to $\mathrm{s}_{\mathrm{u}}$ measured using other index tests, and accounts for probe geometry and differences in loading mechanics (cf. Boscardin 2007 for more information). The cores were cut into sections for measurement to account for the maximum $12 \mathrm{~cm}$ penetration depth of the T-bar, and results were combined into a single profile for each core. 


\section{Results}

Pockmark presence/absence, 1999-2008

Dataset subtraction yielded no detectable change in pockmark frequency, distribution, or morphology in the 19992008 study interval. The area $\left(12.7 \mathrm{~km}^{2}\right)$ coincidently surveyed in all three surveys consistently contained 1,153 pockmarks. The area of overlap between the 2006 and 1999 datasets $\left(25 \mathrm{~km}^{2}\right)$ invariably contained 1,727 pockmarks (Fig. 1).

Pockmarks did not detectably change in roundness, merge with other pockmarks, or significantly $(>5 \mathrm{~m})$ enlarge in lateral extent. Furthermore, there was no visual or geophysical evidence of any plumes emanating from the pockmarks.

\section{Historical data}

The 1948 Descriptive Report clearly identifies pockmarks (USCGS 1948). After initial concerns that the fathometer was giving "misses", the survey devoted special attention to these features, by collecting a denser spacing of soundings (Fig. 3a). Subsequent splits, crosslines, and finally a development along what appeared to be the axis of a possible trench confirmed the presence of pockmarks (p. 5), with the summary noting that "the bottom here is flat with holes from 5 to 25 feet deeper than the general bottom depths" (p. 2). The report also recognized that the earlier surveys of 1872 indeed indicated the presence of deep holes, though the excessively wide line spacing failed to better resolve these.

Despite data and projection differences, the historic contours of 1872 and 1947 generally correspond to the modern pockmark chains, with an exception in the north (Fig. 3b, data for 2006). The crenulated contours more tightly follow the chains in the western portion of the field, where more soundings were collected in 1947, and vessels were closer to topographic stations. The eastern contours mimic the shape of prominent pockmark chains, but spatially do not line up well, nor do they recognize the northern extent of a prominent chain. Nevertheless, the 100 -foot contour roughly corresponds to some of the deepest combined pockmarks imaged in the modern surveys.

\section{Radionuclide activity}

Within the pockmark field, the cores were collected at the base of a pockmark (cores PBBC-08-03, PBBC-08-04), on the sidewall of this pockmark (PBBC-08-05), and outside this pockmark approx. midway to a neighboring pockmark (PBBC-08-07; Fig. 4). The other two cores were $>0.5 \mathrm{~km}$ away from any pockmarks (PBBC-08-01, PBBC-08-09).
There is an overall downcore decline in ${ }^{210} \mathrm{~Pb}$ activity both inside the study pockmark (PBBC-08-04) and outside the pockmark field (PBBC-08-09), but in neither case do the values reach background levels (Fig. 5). Radionuclide activity varies over a wider range inside the pockmark.

The presence of ${ }^{137} \mathrm{Cs}$ in both these cores indicates that sediment has accumulated both within and beyond the confines of the pockmark field since the period of maximum atmospheric nuclear testing in 1963-1964. The downcore profiles reveal multiple ${ }^{137} \mathrm{Cs}$ peaks, particularly in core PBBC-08-04 inside the study pockmark (Fig. 5a).

\section{Undrained shear strength}

Undrained shear strength ranges between 0 and $7 \mathrm{kPa}$ for the four cores collected within and beyond the pockmark field (Fig. 6). These minimal strength values can be considered as typical for "very soft soils", according to Holtz and Kovacs (1981). The data show $\mathrm{s}_{\mathrm{u}}$ generally increasing downcore, at least to $0.2 \mathrm{~m}$ core depth. Within this depth interval, the $s_{\mathrm{u}}$ profiles outside the pockmark field (core PBBC-08-01), at the base of the study pockmark (PBBC-08-03), and in between two pockmarks (PBBC-08$07)$ reached maximum values of $3.6,2.2$, and $1.6 \mathrm{kPa}$, respectively. The core collected on the sidewall of the study pockmark wall (PBBC-08-05) recorded the greatest strength, i.e., $6.5 \mathrm{kPa}$. Sharp peaks in shear-strength values (e.g., PBBC-08-07) may reflect sedimentary layering, or the presence of a harder object such as a twig, pebble or sand grain.

\section{Discussion and conclusions}

Long-term bathymetry

Using co-located swath bathymetry surveys for seafloor change analysis is still a novel technique, with baseline datasets dating back only to the late 1990s (Table 1). In its first application to pockmark-longevity assessment, the method characterized macro-scale $(>5 \mathrm{~m})$ evolution of tens of square kilometers of highly irregular seafloor. However, it was not possible to resolve smaller-scale changes due to offsets between datasets. Such offsets are common in difference analyses of steeply sloping features (cf. Smith et al. 2005; Hughes Clarke et al. 2009), and are particularly evident when data are not collected using RTK positioning (this study). That such artifacts exist even in studies using high-quality modern swath bathymetry data underscores the need for caution when interpreting "change" among datasets of varying resolution and quality, especially in areas with complex seafloors. 
Fig. 3 a Overlapped Smooth Sheets containing the original soundings (in feet) from historical surveys (US Coast Survey 1872a,b; USCGS 1947) roughly projected over Belfast Bay. Survey H1106 (1872), mostly overlain by H7198 (1947), covered the western portion of the field and H1258 (1872) the east. We drew 60 -foot $(18.5 \mathrm{~m})$ and 100 -foot ( $30 \mathrm{~m}$; field center) contour lines around the soundings, though in some instances we traced contours already lightly drawn on the smooth sheets, presumably by someone associated with the surveys. b 2006 bathymetry overlain by the rendered historical contours
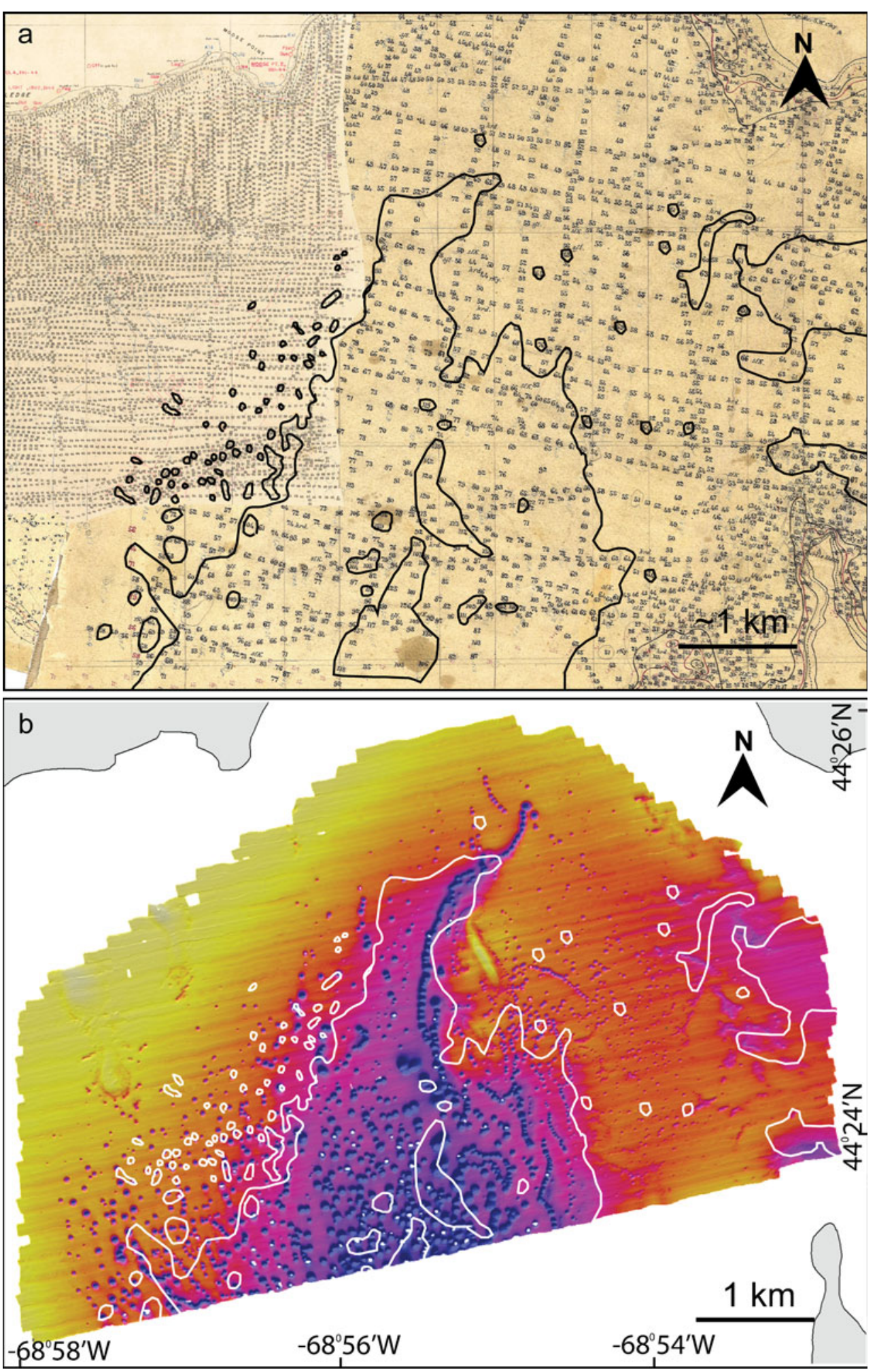

Incorporating historical data temporally extended this study's presence/absence analysis, though in significantly less detail (i.e., pockmark frequency and distribution could not be quantified). Differences in navigation and projection may account for tens of meters of offset between the historic $(1872,1947)$ and modern $(1999,2006,2008)$ datasets. Similarly, distinct line spacing, vertical references, and the arbitrary association of the 60 -foot $(18.5 \mathrm{~m})$ contour with pockmark chains could explain the lack of full chain accordance between the surveys $(1872,1947,2006)$. The fact remains that pockmark chains existed in 1872, and coupled with the lack of major change between 1999 and 


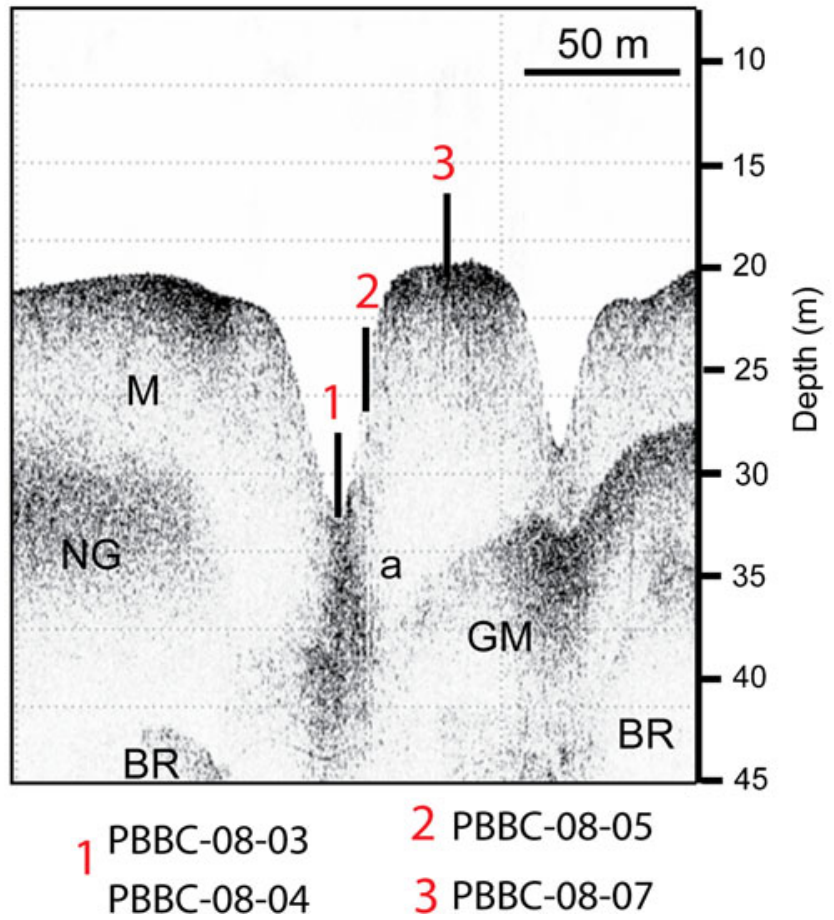

Fig. 4 Locations of the group of four box cores collected within the pockmark field (cf. Fig. 1), superimposed on CHIRP sonar data. Interpreted units are the same as in Fig. 2: $M$ Holocene mud, $G M$ glacial-marine sediment, $N G$ natural gas, $B R$ bedrock, $a$ intrasedimentary doming

2008, the data strongly suggest that the field existed in a form similar to the present at least 140 years ago. These results both directly document minimal pockmark age, and provide strong support to the hypothesis/conventional wisdom that pockmarks are long-lived features (cf. Judd and Hovland 2007).

a

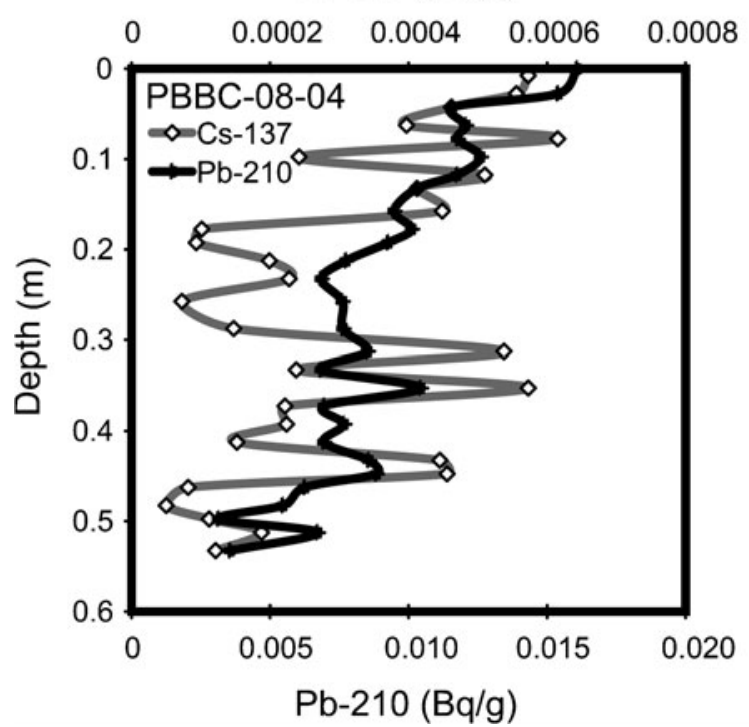

Undrained shear strength

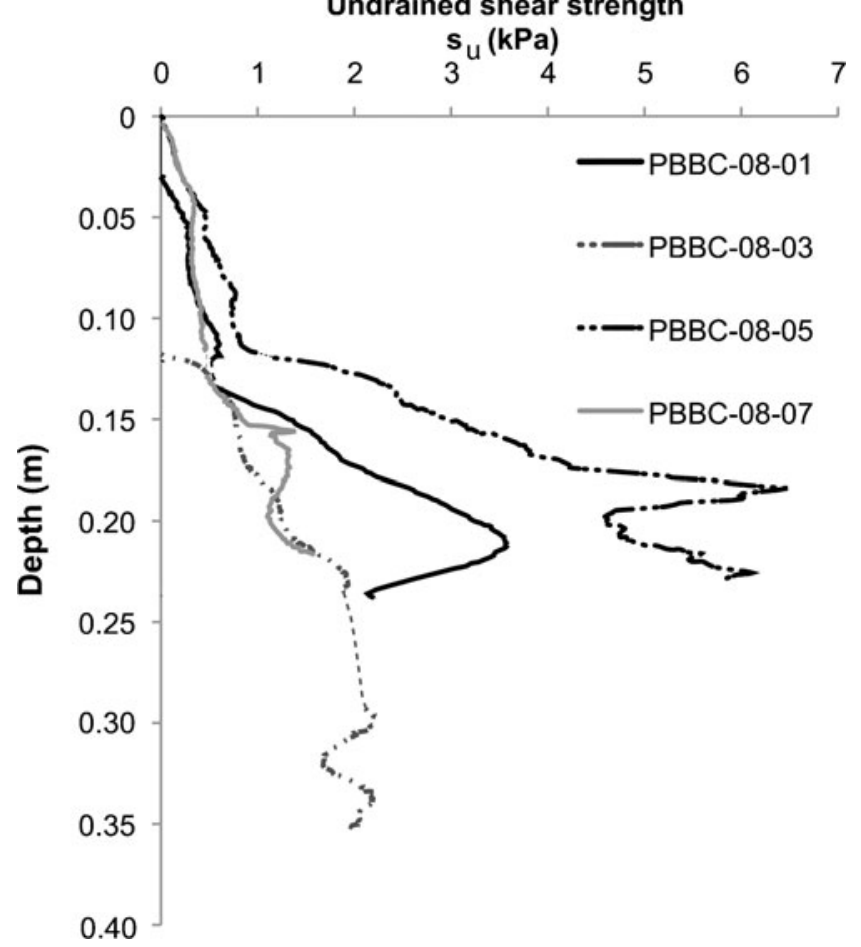

Fig. 6 Undrained shear strength $\left(\mathrm{s}_{\mathrm{u}}\right)$ of the four box cores: cores PBBC-08-03, PBBC-08-05, and PBBC-08-07 are located within the pockmark field, core PBBC-08-01 beyond the confines of the field (cf. main text for more information). Due to the height restrictions imposed by the load frame, it was not possible to measure the top $12 \mathrm{~cm}$ of PBBC-08-03

Core-based evidence of sediment reworking

Since neither core tested for radionuclide activity reached background levels of ${ }^{210} \mathrm{~Pb}$, the data are not suitable for the

b

Cs-137 (Bq/g)

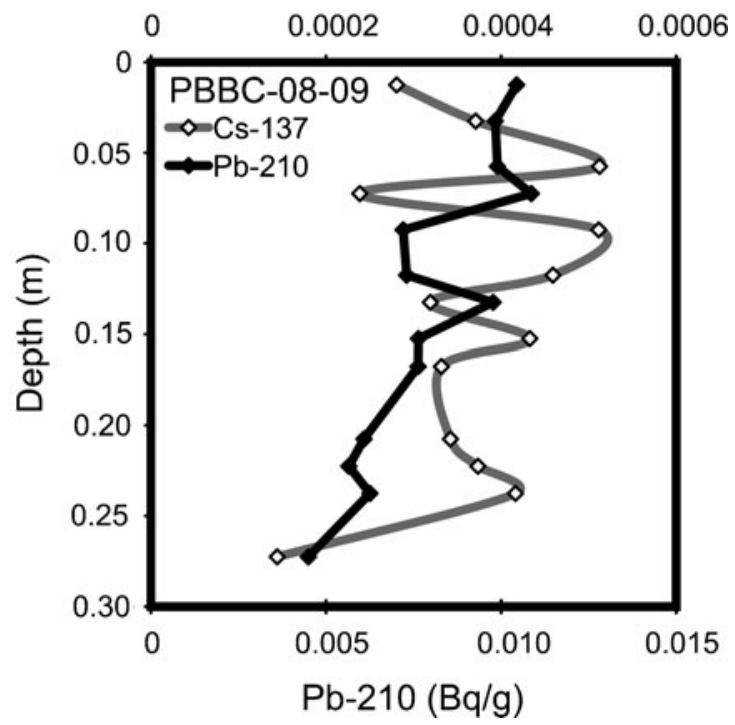

Fig. 5 Downcore radionuclide activity profiles in a core PBBC-08-04 (base of pockmark), and b core PBBC-08-09 (outside the pockmark field) 
Table 1 Selected studies (in chronological order) from the last ca. 5 years using repeat swath bathymetry surveys for seafloor change detection

\begin{tabular}{|c|c|c|c|c|c|}
\hline Reference & Location of repeat surveys & $\begin{array}{l}\text { Period of } \\
\text { observation } \\
\text { (months) }\end{array}$ & $\begin{array}{l}\text { Number of } \\
\text { surveys }\end{array}$ & $\begin{array}{l}\text { Years datasets were } \\
\text { acquired }\end{array}$ & Research subject of repeat surveys \\
\hline $\begin{array}{l}\text { Ferrini and Flood } \\
\text { (2005) }\end{array}$ & $\begin{array}{l}\text { Shinnecock Inlet, Long Island, New } \\
\text { York (NY), USA; } \\
\text { Eel River Margin, California } \\
\text { (CA), USA }\end{array}$ & $42 \mathrm{NY} ; 11 \mathrm{CA}$ & $6 \mathrm{NY} ; 2 \mathrm{CA}$ & 1998-2002; 1999, 2000 & Ripple scour depression evolution \\
\hline $\begin{array}{l}\text { Knaapen et al. } \\
(2005)\end{array}$ & $\begin{array}{l}\text { North Sea, between UK and The } \\
\text { Netherlands }\end{array}$ & 12 & 22 & $2000-2001$ & $\begin{array}{l}\text { Bedform migration, small to medium } \\
\text { dunes }\end{array}$ \\
\hline Smith et al. (2005) & $\begin{array}{l}\text { Monterey Canyon, Monterey Bay, } \\
\text { CA, USA }\end{array}$ & 6 & 3 & $2002-2003$ & Submarine canyon geomorphic change \\
\hline Smith et al. (2007) & $\begin{array}{l}\text { Monterey Canyon, Monterey Bay, } \\
\text { CA, USA }\end{array}$ & 29 & 7 & $2002-2005$ & Submarine canyon geomorphic change \\
\hline $\mathrm{Xu}$ et al. (2008) & $\begin{array}{l}\text { Monterey Canyon, Monterey Bay, } \\
\text { CA, USA }\end{array}$ & 35 & 7 & 2003-2006 & Sandwave migration \\
\hline $\begin{array}{l}\text { Barrie et al. } \\
\text { (2009) }\end{array}$ & $\begin{array}{l}\text { Inner continental shelf of the } \\
\text { Canadian Pacific } \\
\text { Margin, Boundary Pass (BP) } \\
\text { and Eastern Juan } \\
\text { de Fuca Strait (JFS) }\end{array}$ & 48 BP; 96 JFS & $5 \mathrm{BP} ; 2 \mathrm{JFS}$ & $\begin{array}{l}\text { 2001, 2003, 2004, 2006; } \\
\quad \text { 1998, } 2006\end{array}$ & Very large dune migration \\
\hline $\begin{array}{l}\text { Hughes Clarke et } \\
\text { al. (2009) }\end{array}$ & $\begin{array}{l}\text { Squamish River Delta, BC, Canada; } \\
\text { Oliver Sound, } \\
\text { Baffin Island (BI), Canada }\end{array}$ & $48 \mathrm{BC} ; 12 \mathrm{BI}$ & $6 \mathrm{BC} ; 2 \mathrm{BI}$ & $2003-2007$ & $\begin{array}{l}\text { Temperate and Arctic fjord delta } \\
\text { evolution }\end{array}$ \\
\hline $\begin{array}{l}\text { Marani et al. } \\
\text { (2009) }\end{array}$ & Stromboli Island, Italy & 45 & 2 & 1999,2003 & Island volcano flank pre/post landslide \\
\hline $\begin{array}{l}\text { Foucher et al. } \\
\text { (2010) }\end{array}$ & $\begin{array}{l}\text { Håkon Mosby mud volcano, } \\
\text { offshore northern } \\
\text { Norway }\end{array}$ & 36 & 2 & 2003,2006 & $\begin{array}{l}\text { Mud volcano geomorphic evolution and } \\
\text { activity }\end{array}$ \\
\hline Hill (2011) & Fraser River Delta, western Canada & 143 & 8 & $\begin{array}{l}1994,2000-2003,2005 \\
2006\end{array}$ & $\begin{array}{l}\text { Channel system evolution and sediment } \\
\text { wave origin resolution }\end{array}$ \\
\hline This study & Belfast Bay, Maine, USA & 112 & 3 & $1998,2006,2008$ & Pockmark field geomorphic evolution \\
\hline
\end{tabular}

generation of any age model. Furthermore, due to multiple ${ }^{137} \mathrm{Cs}$ peaks within each core, no attempt was made to assign an age to any single peak and to assess sediment accumulation. Concordant spikes in radionuclide activity likely reflect changes in grain size (Nittrouer et al. 1979). Any post-depositional mobility of ${ }^{137} \mathrm{Cs}$ (cf. Davis et al. 1984) is improbable in these sediments because of the low organic content ( $<10 \%$ loss on ignition; Brothers 2010). Instead, these isotopic trends in the box cores are interpreted to indicate a highly disturbed near-bed environment both inside and outside the pockmarks. Combined with the erratic radiocarbon ages reported by Ussler et al. (2003), these radionuclide signatures suggest that sediments are regularly reworked, and steady sediment accumulation does not characterize this environment. Potential mechanisms that can introduce and rework sediments within an estuarine pockmark include fluvial deposition, slumping of pockmark walls, fluid venting, near-bed resuspension, anthropogenic disturbance (e.g., fishing practices, anchorages), and bioturbation.

The minimal strength values for the intact core samples are comparable to those found in other offshore finegrained sediments (e.g., Randolph 2004), and corroborate other lines of evidence (cf. above) that the field's shallow sediments could be easily disturbed. We found the greatest shear strength in a sample collected on a pockmark wall, which could reflect the scouring away of weaker sediments and the exposure of more consolidated material.

\section{Pockmark field longevity and venting?}

Belfast Bay stratigraphy indicates that pockmarks must have formed following the sea-level lowstand, and thus have a maximum potential age of 12,500 years B.P.; historical records constrain at least some of the field's pockmarks to a minimum age of 140 years. While this study temporally constrains major seafloor morphologic changes, the methods were not suited for detailed characterization of seafloor venting. In place of that, we reconcile the observations of Ussler et al. (2003) with Rogers et al. (2006), and conclude that this field does not persistently vent fluid from every pockmark. Assuming that fluid escape is the mechanism responsible for pockmarks, our finding that essentially no new pockmarks $(>5 \mathrm{~m})$ formed over 9 years (1999-2008) may mean that no venting occurred during this observation period. Alternatively, venting may have occurred but had only weak effects on seafloor morphology (i.e., new pockmarks would have been smaller than our grid resolution $(5 \mathrm{~m})$, and thus went undetected). Whatever the case, the data imply that major 
pockmark formation is episodic, and has not occurred in the last ca. 10 years in Belfast Bay. Furthermore, these integrated observations illustrate that present-day pockmark frequency and distribution do not necessarily reflect modern venting.

Similarly, these data indicate that this field's pockmarks are not prone to collapse or burial. This is a novel finding in an estuarine pockmark field, because one would expect the pockmarks to diminish in such a disturbed setting in the absence of regular fluid venting. That the pockmarks were maintained over the 9-year study period, and likely predated those surveys by at least a century, suggests that the pockmarks do not require protracted venting for preservation, and that other mechanisms are evidently capable of maintaining the pockmarks. One such possible mechanism, explored in observational and modeling work by Manley et al. (2004) and Hammer et al. (2009), is upwelling within pockmarks induced by weak near-bed currents. Although near-bed currents in Belfast Bay are not expected to exceed $0.2 \mathrm{~ms}^{-1}$, they should suffice to induce upwelling in pockmarks that would be strong enough to prevent accumulation of fine-grained sediments, thereby maintaining the pockmarks in the study area. Clearly, this aspect warrants further research, strengthening the call for longterm monitoring of pockmarks, particularly with regard to inner pockmark physical and geochemical conditions.

Acknowledgements Graduate support for Brothers came from a Maine Economic Improvement Fund Dissertation Fellowship. Thomas Hess, and the University of Maine Honors College provided gamma counts. We thank Don J. Degroot for use of facilities at the University of Massachusetts Geotechnical Laboratory. This work would not have been possible without the technical and analytical skills of Emile Bergeron, Bill Danforth, Barry Irwin, and Chuck Worley. We are grateful to Captain Randy Flood and the crew of the R/V Argo, Robin Arnold, Adriane Boscardin, Doug Cahl, Bob Johnson, Randall Perry, and Ashley Stinson for field and lab assistance. Reidulv Bøe, Bill Schwab, Daniel Brothers, and editors Burg Flemming and Monique Delafontaine generously provided helpful reviews of earlier drafts of this manuscript. Any use of trade names is only for descriptive purposes and does not imply endorsement by the US Government.

\section{References}

Andrews BD, Brothers LL, Barnhardt WA (2010) Automated feature extraction and spatial organization of seafloor pockmarks, Belfast Bay, Maine, USA. Geomorphology 124(1/2):55-64

Arnold R (2002) Investigation of potential mechanisms for methane escape in Belfast Bay's giant pockmark field: analysis of remotely operated vehicle (ROV) data. Honors Thesis, University of Maine, Orono, ME

Barnhardt WA, Gehrels WR, Belknap DF, Kelley JT (1995) Late Quaternary relative sea-level change in the western Gulf of Maine: evidence for a migrating glacial forebulge. Geology 23 (4):317-320

Barnhardt WA, Belknap DF, Kelley AR, Kelley JT, Dickson SM (1996) Geologic Map Series Nos. 96-7-13, 1:100,000. Maine Geological Survey, Augusta, ME
Barnhardt WA, Belknap DF, Kelley JT (1997) Stratigraphic evolution of the inner continental shelf in response to late Quaternary relative sea-level change, northwestern Gulf of Maine. Geol Soc Am Bull 109:612-630

Barrie JV, Conway KW, Picard K, Greene HG (2009) Large-scale sedimentary bedforms and sediment dynamics on a glaciated tectonic continental shelf: examples from the Pacific margin of Canada. Cont Shelf Res 29:796-806

Belknap DF (1991) Submersible investigation of seafloor pockmarks, central Maine coast: geology and biology of natural gas (?) craters. Final report to NOAA National Undersea Research Center. University of Connecticut, Storrs, CT

Belknap DF, Shipp RC (1991) Seismic stratigraphy of glacial marine units, Maine inner shelf. In: Anderson JB, Ashley GM (eds) Glacial marine sedimentation; paleoclimatic significance. Geological Society of America, Boulder, CO, pp 137-157, Spec Pap 261

Belknap DF, Andersen BG, Anderson RS, Anderson WA, Borns HW Jr, Jacobson G Jr, Kelley JT, Shipp RC, Smith DC, Stuckenrath R Jr, Thompson WB, Tyler DA (1987) Late Quaternary sea-level changes in Maine. In: Nummedal D, Pilkey OH Jr, Howard JD (eds) Sea-level fluctuation and coastal evolution. SEPM Spec Publ 41:71-85

Belknap DF, Kraft JC, Dunn RK (1994) Transgressive valley fill lithosomes: Delaware and Maine. In: Boyd R, Zaitlin BA, Dalrymple R (eds) Incised valley fill systems. SEPM Spec Publ 51:303-320

Bøe R, Rise L, Ottesen D (1998) Elongate depressions on the southern slope of the Norwegian Trench (Skagerrak): morphology and evolution. Mar Geol 146:191-203

Boland GS, Rowe GT (1991) Deep-sea benthic sampling with the GOMEX box corer. Limnol Oceanogr 36(5):1015-1020

Boscardin AG (2007) Evaluation of miniature full flow penetrometers and push cone for laboratory measurement of remolded undrained shear strength of soft clays. MSc Thesis, University of Massachusetts, Amherst, MA

Brothers LL (2010) Nearshore pockmark field dynamics and evolution. PhD Thesis, University of Maine, Orono, ME

Brothers LL, Belknap DF, Kelley JT, Janzen CD (2008) Sediment transport and dispersion in a cool-temperate estuary and embayment, Saco River estuary, Maine, USA. Mar Geol 251(3/ 4):183-194

Christian HA (2000) Gas sampling and seepage liquefaction assessment in Penobscot Bay, Maine, December 1999. Report to the Department of Geological Sciences, University of Maine. Christian Situ Geosciences, Halifax, Nova Scotia

Davis RB, Hess CT, Norton SA, Hanson DW, Hoagland KD, Anderson DS (1984) ${ }^{137} \mathrm{Cs}$ and ${ }^{210} \mathrm{~Pb}$ dating of sediments from soft-water lakes in New England (U.S.A.) and Scandinavia, a failure of ${ }^{137} \mathrm{Cs}$ dating. Chem Geol 44:151-185

Dorion CC, Balco GA, Kaplan MR, Kreutz KJ, Wright JD, Borns HW Jr (2001) Stratigraphy, paleoceanography, chronology, and environment during deglaciation of eastern Maine. In: Weddle TK, Retelle MJ (eds) Deglacial history and relative sea-level changes, northern New England and adjacent Canada. Geol Soc Am Spec Pap 351:215-242

Fader GBJ (1991) Gas-related sedimentary features from the eastern Canadian continental shelf. Cont Shelf Res 11:11231154

Fenster MS, FitzGerald DM, Kelley JT, Belknap DF, Buyenvitch IV, Dickson SM (2001) Net ebb sediment transport in a rock-bound, mesotidal estuary during spring freshet conditions: Kennebec River estuary, Maine. GSA Bull 113:1522-1531

Ferrini VL, Flood RD (2005) A comparison of rippled scour depressions identified with multibeam sonar: evidence of sediment transport in inner shelf environments. Cont Shelf Res 25:1979-1995 
Fleischer P, Orsi TH, Richardson MD, Anderson AL (2001) Distribution of free gas in marine sediments: a global overview. Geo-Mar Lett 21(2):103-122. doi:10.1007/s003670100072

Foucher J, Dupré S, Scalabrin C, Feseker T, Harmegnies F, Nouzé H (2010) Changes in seabed morphology, mud temperature and free gas venting at the Håkon Mosby mud volcano, offshore northern Norway, over the time period 2003-2006. Geo-Mar Lett 30(3/ 4):157-167. doi:10.1007/s00367-010-0193-Z

Gontz AM (2002) Evolution of seabed pockmarks in Penobscot Bay, Maine. MSc Thesis, University of Maine, Orono, ME

Hammer Ø, Webb KE, Depreiter D (2009) Numerical simulation of upwelling currents in pockmarks, and data from the Inner Oslofjord, Norway. Geo-Mar Lett 29(4):269-275. doi:10.1007/ s00367-009-0140-Z

Hill PR (2011) Changes in submarine channel morphology and strata development from repeat multibeam surveys in the Fraser River delta, western Canada. In: Li MZ, Sherwood CR, Hill PR (eds) Sediments, morphology and sedimentary processes on continental shelves. Spec Publ International Association of Sedimentologists, Wiley-Blackwell, Hoboken, NJ (in press)

Holtz RD, Kovacs WD (1981) An introduction to geotechnical engineering. Prentice Hall, Englewood Cliffs

Hovland A, Judd AG (1988) Seabed pockmarks and seepages: impact on geology, biology, and the marine environment. Graham and Trotman, London

Hovland M, Judd AG, King LH (1984) Characteristic features of pockmarks on the North Sea Floor and Scotian Shelf. Sedimentology 31:471-480

Hovland M, Svensen H, Forsberg CF, Johansen H, Fichler C, Fosså JH, Jonsson R, Rueslåtten H (2005) Complex pockmarks with carbonate-ridges off mid-Norway: products of sediment degassing. Mar Geol 218:191-206

Hovland M, Heggland R, De Vries MH, Tjelta TI (2010) Unit-pockmarks and their potential significance for predicting fluid flow. Mar Petrol Geol 27(6):1190-1199. doi:10.1016/j.marpetgeo.2010.02.005

Hughes Clarke JE, Brucker S, Hill P, Conway K (2009) Monitoring morphological evolution of fjord deltas in temperate and arctic regions. In: Chiocci FL, Ridente D, Bosman A (eds) Ext Abstr Int Conf Seafloor Mapping for Geohazard Assessment, Lerici, Italy. Soc Geol Italiana 7(4):147-150

Hustoft S, Bünz S, Mienert J, Chand S (2009) Gas hydrate reservoir and active methane-venting province in sediments on $<20 \mathrm{Ma}$ young oceanic crust in the Fram Strait, offshore NW-Svalbard. Earth Planet Sci Lett 284:12-24

Iglesias J, García-Gil S (2007) High-resolution mapping of shallow gas accumulations and gas seeps in San Simón Bay (Ría de Vigo, NW Spain). Some quantitative data. Geo-Mar Lett 27(2/4):103114. doi:10.1007/s00367-007-0065-3

Josenhans HW, King LH, Fader GBJ (1978) Side-scan sonar mosaic of pockmarks on Scotian Shelf. Can J Earth Sci 15:831-840

Judd AG, Hovland M (2007) Seabed fluid flow. Cambridge University Press, Cambridge

Kelley JT (1987) An inventory of coastal environments and classification of Maine's glaciated shoreline. In: FitzGerald DM, Rosen PS (eds) Glaciated coasts. Academic, San Diego, pp 151-176

Kelley JT, Belknap DF (1991) Physiography, surficial sediments and Quaternary stratigraphy of the inner continental shelf and nearshore region of central Maine, United States of America. Cont Shelf Res 11:1265-1283

Kelley JT, Dickson SM, Belknap DF, Barnhardt WA, Henderson M (1994) Giant sea-bed pockmarks: evidence for gas escape from Belfast Bay, Maine. Geology 22:59-62

Kelley JT, Belknap DF, Claesson S (2010) Drowned coastal deposits with associated archaeological remains from a sea-level "slowstand": Northwestern Gulf of Maine, USA. Geology 38(8):695698
King LH, Fader GBJ (1986) Wisconsinan glaciation of the Atlantic continental shelf of southeast Canada. Geol Surv Can Bull 363:1-72

King LH, MacLean B (1970) Pockmarks on the Scotian Shelf. Geol Soc Am Bull 81:3141-3148

Knaapen MAF, van Bergen Henegouw CN, Hu YY (2005) Quantifying bedform migration using multi-beam sonar. Geo-Mar Lett 25(5):306-314. doi:10.1007/s00367-005-0005-z

Manley PL, Manley TO, Watzin MC, Gutierrez J (2004) Lakebed pockmarks in Burlington Bay, Lake Champlain: I. Hydrodynamics and implications of origin. In: Manley TO, Manley PL, Mihuc TB (eds) Lake Champlain: partnerships and research in the new millennium. Berlin Heidelberg New York, Springer, pp 299-330

Marani MP, Gamberi F, Rosiss M, Bertagnini A, di Roberto A (2009) Subaqueous density flow processes and deposits of an island volcano landslide (Stromboli Island, Italy). Sedimentology 56:1488-1504. doi:10.1111/j.1365-3091.2008.01043.x

Mazurenko LL, Soloviev VA (2003) Worldwide distribution of deepwater fluid venting and potential occurrences of gas hydrate accumulations. Geo-Mar Lett 23(3/4):162-176. doi:10.1007/ s00367-003-0146-X

Nelson H, Thor DR, Sandstrom MW, Kvenvolden KA (1979) Modern biogenic gas-generated craters (sea-floor "pockmarks") on the Bering Shelf, Alaska. Geol Soc Am Bull 90:1144-1152

Nittrouer CA, Sternberg RW, Carpenter R, Bennett JT (1979) The use of $\mathrm{Pb}-210$ geochronology as a sedimentological tool: application to the Washington Continental Shelf. Mar Geol 31:297-316

NOAA (2000) Descriptive Report H-10867. National Oceanic and Atmospheric Administration, US Government Printing Office, Washington, DC

Osberg PH, Hussy AM II, Boone GM (1985) Bedrock geologic map of Maine, 1:500, 000. Maine Geological Survey, Augusta, ME

Paull C, Ussler W III, Maher N, Greene HG, Rehder G, Lorenson T, Lee H (2002) Pockmarks off Big Sur, California. Mar Geol 181:323-335

PEARL (2011) Penobscot River Synthesis. http://www.pearl.maine. edu/windows/penobscot/research_hydrology.htm

Randolph MF (2004) Characterization of soft sediments for offshore applications. In: Viana da Fonseca A, Mayne PW (eds) Proc ISC2 geotechnical and geophysical site characterization, September 2004, Porto. Millpress, Rotterdam, pp 209-232

Rogers J, Kelley JT, Belknap DF, Gontz A, Barnhardt WA (2006) Shallow-water pockmark formation in temperate estuaries: a consideration of origins in the western gulf of Maine with special focus on Belfast Bay. Mar Geol 225(1/4):45-62

Scanlon KM, Knebel HJ (1989) Pockmarks in the floor of Penobscot Bay, Maine. Geo-Mar Lett 9(1):53-58. doi:10.1007/BF02262818

Smith DP, Ruiz G, Kvitek R, Iampietro PJ (2005) Semiannual patterns of erosion and deposition in upper Monterey Canyon from serial multibeam bathymetry. Geol Soc Am Bull 117(9/10):1123-1133

Smith DP, Kvitek R, Iampietro PJ, Wong K (2007) Twenty-nine months of geomorphic change in upper Monterey Canyon. Mar Geol 236(1/2):79-94

Thompson WB, Borns HW Jr (1985) Surficial geologic map of Maine, 1:500, 000. Maine Geological Survey, Augusta, ME

Tjelta TI, Svan ØG, Strout JM, Forsberg CF, Johansen H, Planke S (2007) Shallow gas and its multiple impact on a North Sea production platform. In: Proc 6th Int Offshore Site Investigation and Geotechnics Conf, SUT-OSIG, London, pp 205-220

USCGS (1947) US Coast Guard \& Geodetic Survey, H07198 Smooth Sheet. National Geophysical Data Center, http://www.ngdc.noaa. gov/mgg/bathymetry/hydro.html

USCGS (1948) US Coast Guard \& Geodetic Survey, H07198 Descriptive Report. National Geophysical Data Center, http:// www.ngdc.noaa.gov/mgg/bathymetry/hydro.html

US Coast Survey (1872a) H1258 Smooth Sheet. National Geophysical Data Center, http://www.ngdc.noaa.gov/mgg/ bathymetry/hydro.html 
US Coast Survey (1872b) H1106 Smooth Sheet. National Geophysical Data Center, http://www.ngdc.noaa.gov/mgg/bathymetry/hydro.html

Ussler W III, Paull CK, Boucher J, Friederich GE, Thomas DJ (2003) Submarine pockmarks: a case study from Belfast Bay, Maine. Mar Geol 202:175-192

Vaular E, Barth T, Haflidason H (2010) The geochemical characteristics of the hydrate-bound gases from the Nyegga pockmark field, Norwegian Sea. Org Geochem 42:437-444

Webb KE, Hammer Ø, Lepland A, Gray JS (2009) Pockmarks in the inner Oslofjord, Norway. Geo-Mar Lett 29(2):111-124. doi:10.1007/s00367-008-0127-1
Whiticar MJ (2002) Diagenetic relationships of methanogenesis, nutrients, acoustic turbidity, pockmarks and freshwater seepages in Eckernförde Bay. Mar Geol 182:29-53

Xu JP, Wong FL, Kvitek R, Smith DP, Paull CK (2008) Sandwave migration in Monterey Submarine Canyon Central CA. Mar Geol 248:193-212

Xue H, Xu Y, Brooks D, Pettigrew NR, Wallinga J (2000) Modelling the circulation in Penobscot Bay, Maine. In: Spaulding MA, Butler HL (eds) Proc 6th Int Conf Estuarine and Coastal Modelling, November 1999, New Orleans. LA. ASCE, New York, pp 1112-1127 